\title{
Development and evaluation of plastic based solar still for production of distilled water
}

\section{S. H. Sengar*, T. V. Chavda and Alok Singh}

Department of Renewable Energy Engineering, College of Agricultural Engineering and Technology, Dediapada, Navasari Agricultural University, Dist. Narmada-393040 (Gujrat), INDIA

*Corresponding author. E-mail: shsengar@nau.in

Received: February 22, 2016; Revised received: December 6, 2016; Accepted: February 11, 2017

Abstract: Solar still was developed and evaluated at Department of Renewable Energy Engineering, College of Agricultural Engineering and Technology, Dediapada. The average yield of distilled water in developed solar still varied from $1055-1498 \mathrm{ml} / \mathrm{m}^{2}$-day during winter and summer where as in already developed still varied 1350 to $1550 \mathrm{ml} / \mathrm{m}^{2}$ day. Thermal efficiency of developed solar still was found as 20 per cent .The physicochemical analysis was carried out to examine the effect of distillation on tap water. A drastic reduction in the TDS, Chlorides, Calcium hardness and magnesium hardness, dissolved silica was observed through solar distillation. The payback period of the unit was only 6 months and after that period the unit produced net profit. The manufacturing cost of this developed solar still was only Rs. 1640/- which was totally manufactured in plastic material so no any corrosive material came in contact for changing the property of distilled water as output. Cleaning of solar still could be easily carried out by just removing the w shape dome of developed device which cannot be possible in available solar still in market.

Keywords: Low cost, Efficiency, TDS, pH, Economics

\section{INTRODUCTION}

It is known fact that it is very difficult to supply drinking water to remote area of our country. These solar distillation plants can be effectively installed in these places where only saline and infected water is available (Lashkaripour and Zivadar ,2005) and where there is no provision of electricity. Because of its simplicity solar distillation plant becomes a desirable option for producing potable water (Velmurugan and Srithar, 2011). both for industrialized and developing nations( Bouchekima, 2003). Beside the drinking purpose, distilled water is also used in chemical experiments, industries, batteries and medical purposes etc (Joseph et.al,2005). The South Gujarat region is enriched with solar energy supply of $450-700 \mathrm{~W} / \mathrm{m}^{2}$ available for 7 to 8 hours in a day. The single slope single basin type desalination unit is commercially available which uses the solar energy for production of desalinated water. The average size of solar desalination unit is 1 sq.m with average output of 1 to 1.5 lit per day. The available solar stills are costlier and difficult to clean (Tarawneh K. 2007) from inside and hence the study was undertaken with objectives as (i) design and development of low cost solar stills using 200 micron polythene sheet and (ii) performance evaluation of solar still for distilled water.

\section{MATERIALS AND METHODS}

\section{System description}

Low cost (W-shape) solar still: Low cost (W-shape) solar still frame was designed and fabricated at Department of Renewable Energy Engineering, College of Agricultural Engineering and Technology (CAET), Dediapada. This still was fabricated using 20 $\mathrm{mm}$ and $100 \mathrm{~mm}$ diameter PVC pipe to make the frame as shown in Plate 1(a). The pipes and corners were well polished and joined with rubber wire to avoid corrosions as well as to protect the polythene sheet from damage. The basin size was $1 \mathrm{~m}$ x $1 \mathrm{~m}$ was prepared with arranging 25 bricks as shown in Plate 1 (b). This still was painted with dull black colour as it absorbs maximum energy and water was impounded with $1-1.5 \mathrm{~cm}$ height in the basin. The UV stabilized 200 micron polythene sheet of size $1.5 \times 2 \mathrm{~m}$ was wrapped properly over the frame so that it became leak proof (Arunkumar, et.al. 2012). The distilled watercollecting channel was made from cut section of 100 mm PVC pipe surrounding the basin as well as it is attached below to the frame with the help of noncorrosive wires shown in Plate 1(c). The collecting channels were fabricated so as to catch the condensed droplets of water inside the solar still. The material used for the fabrication of this unit is presented in Table 1. The water present in basin got evaporated due 
to higher temperature inside the heating chamber. Water vapour inside the heating chamber got condensed in the form of small droplets of water due to lower temperature on inner side of polythene. Condensed droplets of evaporated water were collected through three channels. Surrounding condensed water was collected through third channel from all sides at bottom (Plate 1. d). The cost required to erect $\mathrm{w}$ shape solar still on top of the floor was Rs. 1640/.

Experimental: In this study, low cost solar still was developed with considering theoretical design consideration and evaluated with and without load for production of distilled water in winter and summer. This developed solar still also compared with institutional developed solar still and solar still available in market. Total dissolved solid and $\mathrm{pH}$ were carried out under chemical analysis for distilled water. Cash out flow, cash inflow, present worth of Cash out flow, cash inflow; NPW, BC ratio, payback period etc were carried out under economical analysis for the economic feasibility of a device.

Theoretical design computation: During the theoretical design computation for solar still (Plate 1), peak winter season was considered. In winter season, December month was selected for finding the solar declination angle $(\delta)$, Slope of collector $(\beta)$, intensity of insolation on horizontal and vertical surface and value of $\operatorname{Cos} \theta$. These values are shown in Table 2 . The newly fabricated solar still unit was evaluated for load and no load test and compared with available solar still in market (single slope).

Design considerations: In designing the collector, winter season was selected for design purpose.

Solar collector for plant: The solar collector was designed by using following assumptions:

The device to be situated at latitude of $21^{\circ} 38^{\prime} \mathrm{N}$ and and 73.02 E longitude (Pandey et. al.2005).Minimum insolation on horizontal plane during winter, for $10^{\text {th }}$ of December is $426 \mathrm{~W} / \mathrm{m}^{2}$ (Anna and Rangrajan,1980)

Slope of collector $(\boldsymbol{\beta})$ : In order to calculate the optimum slope of collector, winter was taken as a midpoint. Angle of solar declination $(\delta)$ was calculated from following equation. (Brenidorfer et.al.. 1985)

$\delta=23.45 \sin [0.9863(284+n)]$

where,

$\mathrm{n}=$ Number of days.

Slope of collector $(\beta)$ is calculated by using following formula:

$\beta=(\Phi-\delta)$

where,

$\Phi=$ Latitude at test site, $=21^{\circ} 38^{\prime} \mathrm{N}$

Positive value of $\beta=$ Collector should be south facing.

Intensity of insolation: Instantaneous insolation on the surface was approximately proportional to the cosine of angle of incidence $(\theta)$.

The angle of incidence for insolation falling on south facing roof can be calculated by using following equation. (Brenidorfer et.al.,1985)

$\operatorname{Cos} \theta=\operatorname{Sin} \delta . \operatorname{Sin} \Phi \cdot \operatorname{Cos} \beta-\operatorname{Sin} \delta \cdot \operatorname{Cos} \Phi \cdot \operatorname{Sin} \beta$. $\operatorname{Cos} r+\operatorname{Cos} \delta \cdot \operatorname{Cos} \Phi \cdot \operatorname{Cos} \beta \cdot \operatorname{Cos} \omega+\operatorname{Cos} \delta \cdot \operatorname{Sin} \Phi \cdot$ $\operatorname{Sin} \beta \cdot \operatorname{Cos} r \cdot \operatorname{Cos} \omega+\operatorname{Cos} \delta \cdot \operatorname{Sin} \beta \cdot \operatorname{Sin} r \cdot \operatorname{Sin} \omega$

Where, $\theta=$ Angle of incidence

$\Phi=$ Latitude of the test

$\beta=$ Slope of collector

$\mathrm{r}=$ Surface azimuth angle, for structure this can be considered as its orientation with respect to a north south axis. The angle varies from $-180^{\circ}$ to $+180^{\circ}$, zero is due to south, east is negative and west is positive.

The value of $r=0$ was used for present calculation.

$\omega=$ the hour angle, is the angular displacement at the sun east or west. It is zero at a solar noon and changes $15^{\circ}$ per hour. Morning is negative and afternoon is positive.

$\omega=0$ is used for present calculation.

Following equation was used to determine the intensity of insolation on collector surface $\left(I_{c}\right)$,

$$
I_{c}=I_{h} \times \operatorname{Cos} \theta
$$

Where, $\mathrm{I}_{\mathrm{h}}=$ Intensity of insolation on horizontal surface, $\mathrm{W} / \mathrm{m}^{2}$

For a horizontal surface, since $\beta=0$ and hence, $\operatorname{Cos} \beta$ $=1$ and $\operatorname{Sin} \beta=0$

Now, $\operatorname{Cos} \theta \mathrm{h}=\operatorname{Sin} \delta . \operatorname{Sin} \Phi+\operatorname{Cos} \delta . \operatorname{Cos} \Phi . \operatorname{Cos} \omega$

Hence, level of insolation on sloping surface is calculated as:

$I_{\mathrm{s}}=\mathrm{I}_{\mathrm{h}} \times \operatorname{Cos} \theta / \operatorname{Cos} \theta \mathrm{h}$

\section{RESULTS AND DISCUSSION}

No load test: The low cost $W$-shape solar still with area of $1 \mathrm{~m}^{2}(1 \mathrm{mx} 1 \mathrm{~m})$ was evaluated in winter and summer for no load test. The maximum average temperature observed in winter during no load test was $49.5^{\circ} \mathrm{C}$ at 14 hours and the same time solar intensity was $457 \mathrm{~W} / \mathrm{m}^{2}$, ambient temperature was $32^{\circ} \mathrm{C}$, and outside relative humidity was 32.5 per cent. The trend obtained in no load test during performance testing is as shown in Fig.1. It is revealed that the temperature inside the still increased with solar intensity in morning hours up to 1 P.M., and then started decline as day progressed.

$W$-shape solar still was also evaluated in summer for no load along with solar energy, ambient temperature, inside and outside humidity. In summer, maximum inside temperature reached in solar still was $60.4{ }^{\circ} \mathrm{C}$ where ambient temperature, solar radiation and inside relative humidity were found as $40.2{ }^{\circ} \mathrm{C}, 659 \mathrm{~W} / \mathrm{m}^{2}$ and 24.4 per cent respectively shown in Fig.2.

Load test: $W$-shape solar still was tested with impounding water with $1-1.5 \mathrm{~cm}$ depth in the basin during winter season. The hourly cumulative distilled water obtained was observed with solar intensity, ambient temperature, relative humidity and wind speed in winter shown in Table 3.

It was observed that maximum average temperature 


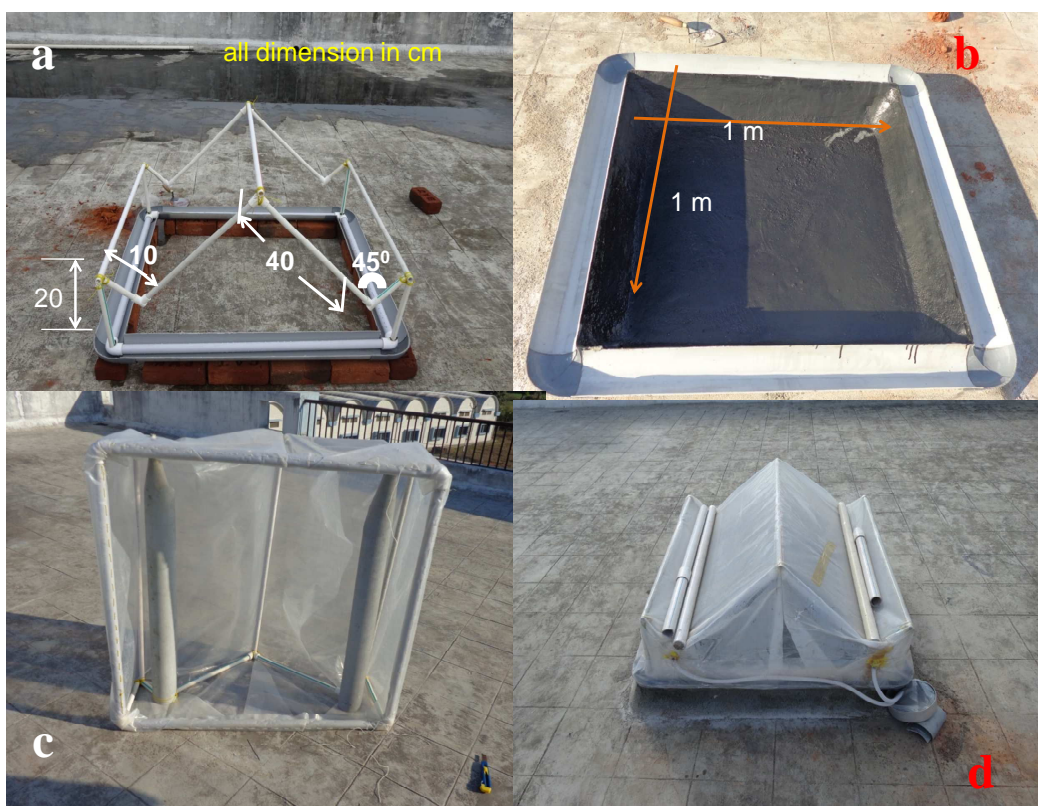

Plate. 1. W shape low cost solar still.

Table 1. Material used for fabrication of Solar still.

\begin{tabular}{|c|c|c|c|c|c|}
\hline $\begin{array}{l}\text { Sr. } \\
\text { No. }\end{array}$ & Item & Specification & $\begin{array}{l}\text { Quantity } \\
\text { required }\end{array}$ & $\begin{array}{c}\text { Rate in } \\
\text { ( })\end{array}$ & $\begin{array}{c}\text { Total Cost } \\
\text { (..) }\end{array}$ \\
\hline 1 & PVC pipe & $20 \mathrm{~mm}$ diameter & $10 \mathrm{~m}$ & $50 / \mathrm{m}$ & $500 /-$ \\
\hline 2 & PVC pipe & $100 \mathrm{~mm}$ diameter & $3 \mathrm{~m}$ & $110 / \mathrm{m}$ & $330 /-$ \\
\hline 3 & Polythene film & $200 \mu, \mathrm{UV}$ protected & $1.5 \times 2 \mathrm{~m}$ & $70 / \mathrm{m}^{2}$ & $210 /-$ \\
\hline 4 & Black paint & & $500 \mathrm{gm}$ & $240 / \mathrm{kg}$ & $120 /-$ \\
\hline 5 & Bricks & & 25 & 6/nug. & $150 /-$ \\
\hline 6 & Cement & 53 grade & $5 \mathrm{~kg}$ & $10 / \mathrm{kg}$ & $50 /-$ \\
\hline 7 & Sand & Fine & $10 \mathrm{~kg}$ & & 80/- \\
\hline 8 & Labor charge & & 1 days & Rs.100/day & 100 \\
\hline 9 & Miscellaneous & & & & 100 \\
\hline \multicolumn{3}{|c|}{ Total cost of solar still } & & & $1640 /-$ \\
\hline
\end{tabular}

Table 2. Details of design computations for solar still.

\begin{tabular}{|c|c|c|c|}
\hline $\begin{array}{l}\mathbf{S} . \\
\mathbf{N}\end{array}$ & Particulars & Symbol & Design parameter of solar still \\
\hline 1 & Solar declination angle & $\delta$ & $\begin{array}{l}\delta=23.45 \sin [0.9863(284+\mathrm{n})] \\
\delta=-23.38\end{array}$ \\
\hline 2 & Slope of collector & $\beta$ & $\begin{array}{l}\beta=(\Phi-\delta) \\
\beta=45^{\circ}\end{array}$ \\
\hline 3 & Solar radiation in December on horizontal surface & $\mathrm{W} / \mathrm{m}^{2}$ & 426 \\
\hline 4 & Value of $\operatorname{Cos} \theta$ & $\operatorname{Cos} \theta$ & 0.98 \\
\hline 5 & Value of $\operatorname{Cos} \theta_{\mathrm{h}}$ & $\operatorname{Cos} \theta_{\mathrm{h}}$ & 0.72 \\
\hline 6 & Intensity of insolation on horizontal & $\mathrm{I}_{\mathrm{c}}$ & $\mathrm{I}_{\mathrm{c}}=\mathrm{I}_{\mathrm{h}} \times \operatorname{Cos} \theta, \mathrm{I}_{\mathrm{c}}=417$ \\
\hline 7 & Intensity of insolation on sloping surface & $\mathrm{I}_{\mathrm{S}}$ & $\mathrm{I}_{\mathrm{s}}=\mathrm{I}_{\mathrm{h}} \times \operatorname{Cos} \theta / \operatorname{Cos} \theta_{\mathrm{h},} \mathrm{I}_{\mathrm{s}}=555 \mathrm{~W} / \mathrm{m}^{2}$ \\
\hline 8 & Cosine of $\theta_{\mathrm{h}}$ & $\theta_{\mathrm{h}}$ & $\theta_{\mathrm{h}}=43^{\circ} .9^{\prime}$ \\
\hline
\end{tabular}


S. H. Sengar et al. / J. Appl. \& Nat. Sci. 9 (1): 427 - 434 (2017)

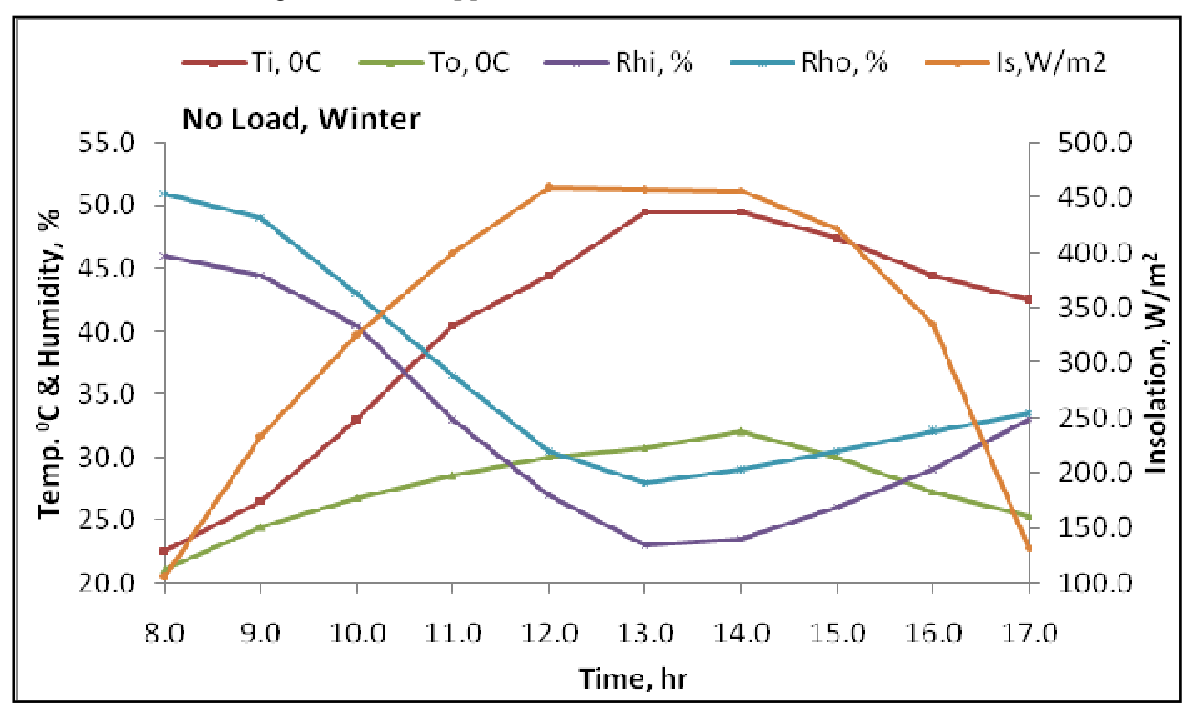

Fig.1. W-shape solar still with no load test in winter.

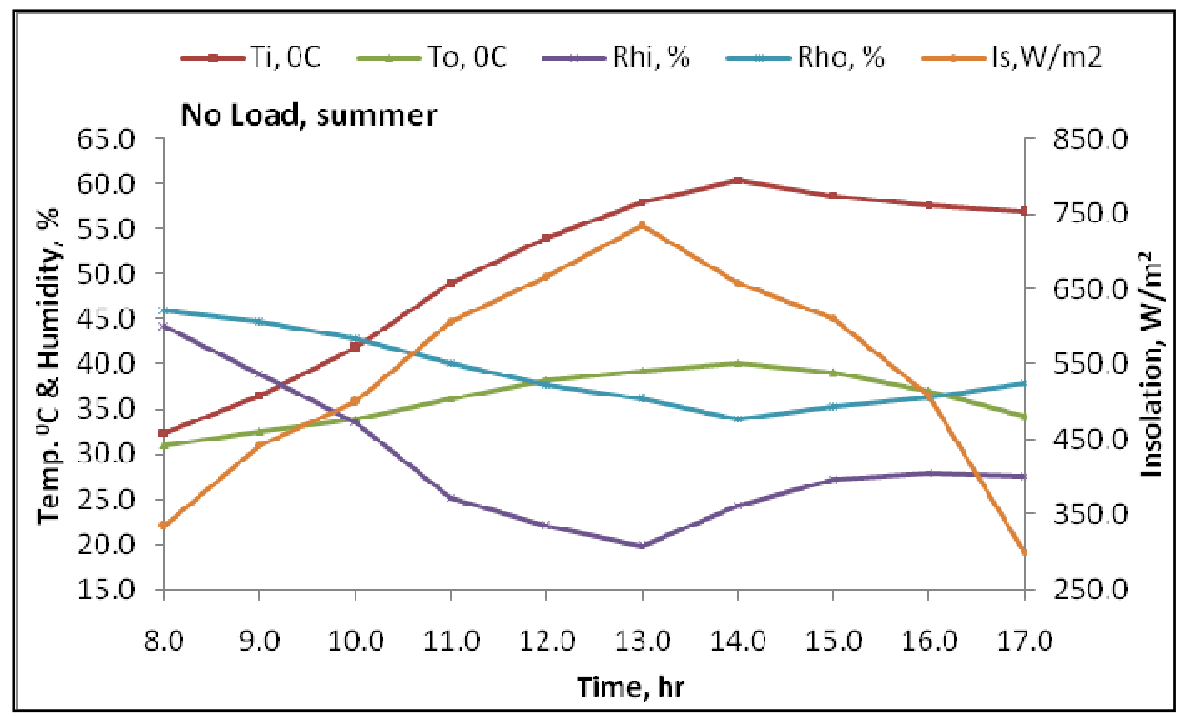

Fig. 2. W-shape solar still with no load test in summer.

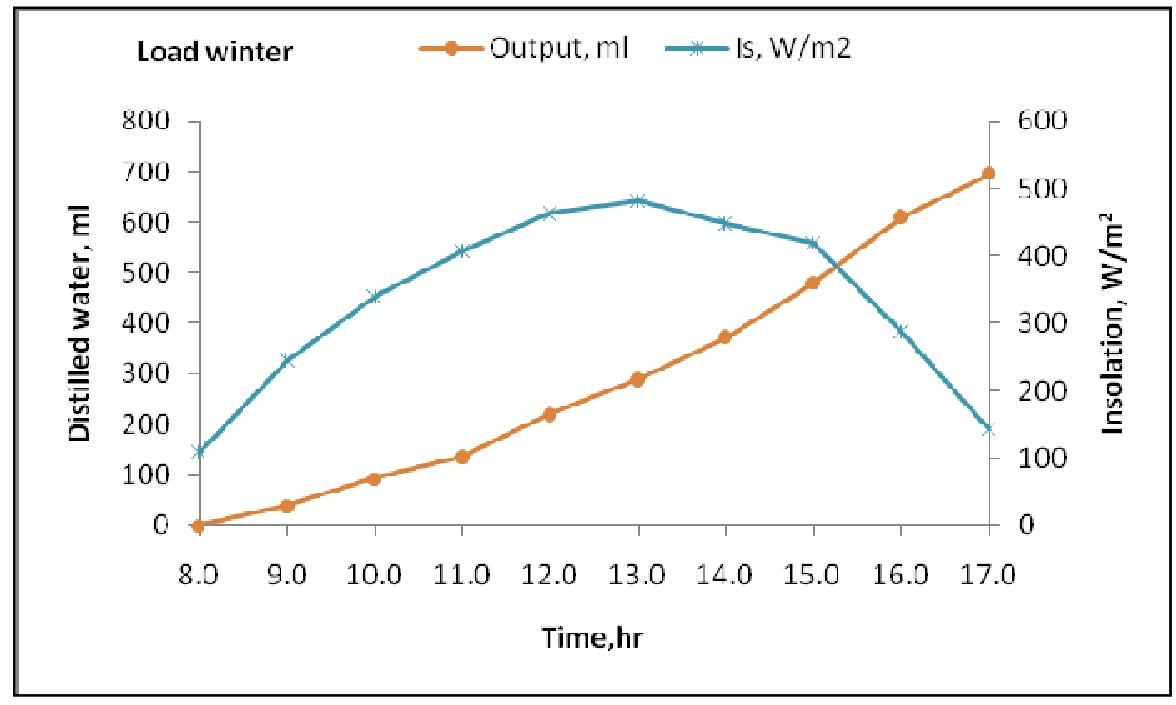

Fig. 3. W-shape solar still during load test in winter 
Table 3. Performance of $W$-shape solar still during load test in winter.

\begin{tabular}{|c|c|c|c|c|c|c|c|}
\hline Time & $\begin{array}{l}\mathrm{Ti}, \\
{ }^{0} \mathrm{C}\end{array}$ & $\begin{array}{l}\text { Ta, } \\
{ }^{0} \mathbf{C}\end{array}$ & $\begin{array}{c}\text { Rhi, } \\
\%\end{array}$ & $\begin{array}{c}\text { Rha, } \\
\%\end{array}$ & $\begin{array}{l}\mathbf{W}, \\
\mathbf{m} / \mathbf{s}\end{array}$ & Is, $\mathbf{W} / \mathbf{m}^{2}$ & $\begin{array}{l}\text { Cu. Disti } \\
\text { water, } m\end{array}$ \\
\hline 8.0 & 28.0 & 21.0 & 73.8 & 43.0 & 0.0 & 109 & 0 \\
\hline 9.0 & 29.5 & 22.8 & 61.5 & 41.0 & 0.0 & 245 & 39 \\
\hline 10.0 & 34.0 & 23.0 & 52.9 & 39.4 & 1.0 & 339 & 93 \\
\hline 11.0 & 38.2 & 26.3 & 42.1 & 34.7 & 0.5 & 407 & 136 \\
\hline 12.0 & 42.0 & 27.3 & 46.2 & 29.5 & 1.2 & 463 & 220 \\
\hline 13.0 & 44.2 & 27.4 & 48.6 & 26.0 & 1.6 & 481 & 289 \\
\hline 14.0 & 43.7 & 27.9 & 49.8 & 25.5 & 1.8 & 448 & 373 \\
\hline 15.0 & 40.8 & 26.7 & 52.7 & 26.0 & 1.7 & 419 & 480 \\
\hline 16.0 & 39.1 & 26.6 & 58.9 & 27.6 & 2.0 & 287 & 610 \\
\hline 17.0 & 35.4 & 24.2 & 62.1 & 29.1 & 1.1 & 143 & 695 \\
\hline Day & & & & & & & 695 \\
\hline Overnight & & & & & & & 360 \\
\hline Total & & & & & & & 1055 \\
\hline
\end{tabular}

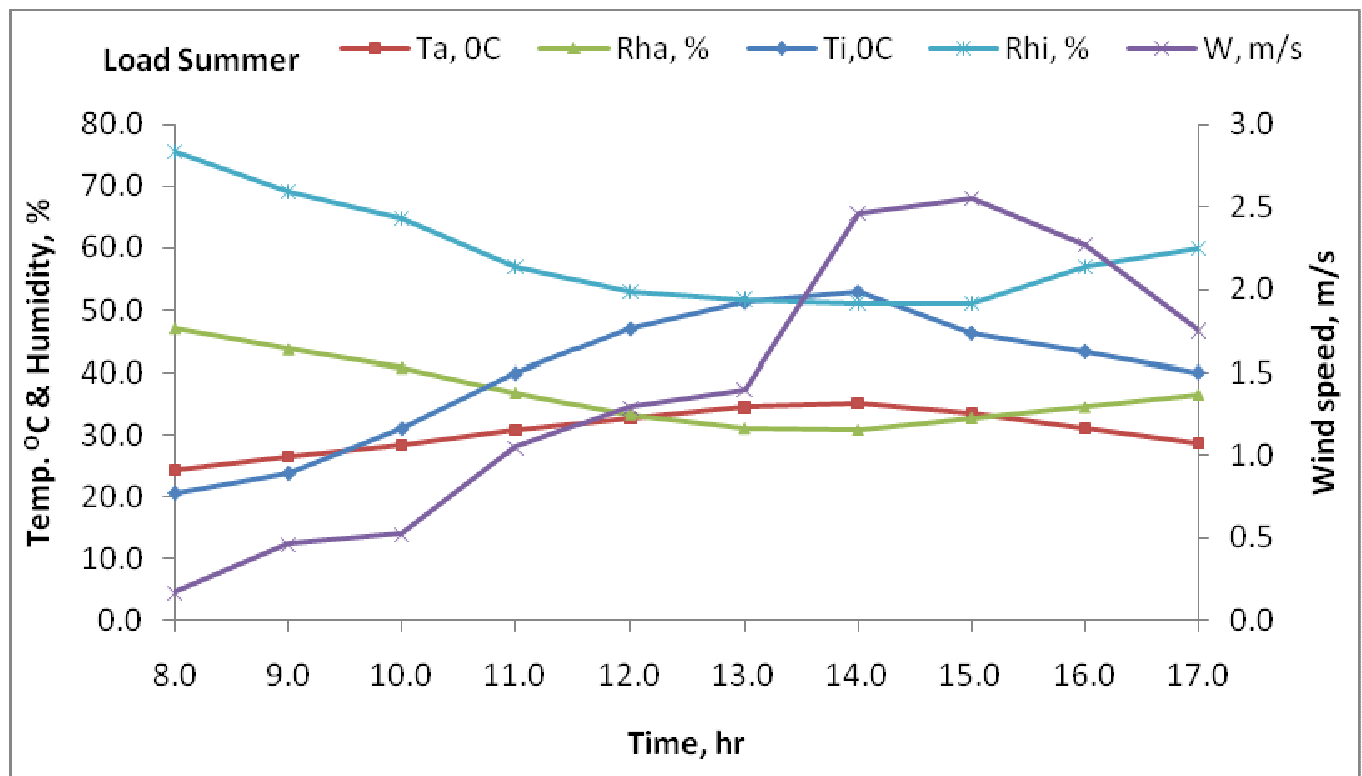

Fig. 4. Climatic parameter with respective time in solar still during load test in summer.

was observed at 1 p.m., when solar intensity was 481 $\mathrm{W} / \mathrm{m}^{2}$ and ambient temperature was $27.9^{\circ} \mathrm{C}$ at 2 p.m, ambient R.H. was 25.5 per cent. It was observed that inside temperature increased as the solar intensity increased and humidity decreases. It was observed that maximum distillation rate obtained between $15 \mathrm{pm}$ to $16 \mathrm{pm}$ which was highest as 107 and $130 \mathrm{ml}$ shown in Fig. 3. Average overnight distillation observed in solar still unit was $360 \mathrm{ml}$ which was due to higher condensation rate at night. The maximum cumulative distillation obtained in winter season was $1055 \mathrm{ml}$, solar in- tensity played vital role in rate and quantity of distillation through the plant.

The performance of solar still during summer, maximum temperature obtained at 2 hours was $52.9^{\circ} \mathrm{C}$, when solar intensity was $622 \mathrm{~W} / \mathrm{m}^{2}$ and ambient temperature was $35.2 .0^{\circ} \mathrm{C}$, ambient R.H. was 30.9 per cent and inside R.H. was 51.2 per cent. Trend observed in load test during performance is shown in Fig 4.

It was observed that inside temperature increased as the solar intensity increased and hence rate heat utilization for heating the water was more in noon time and 


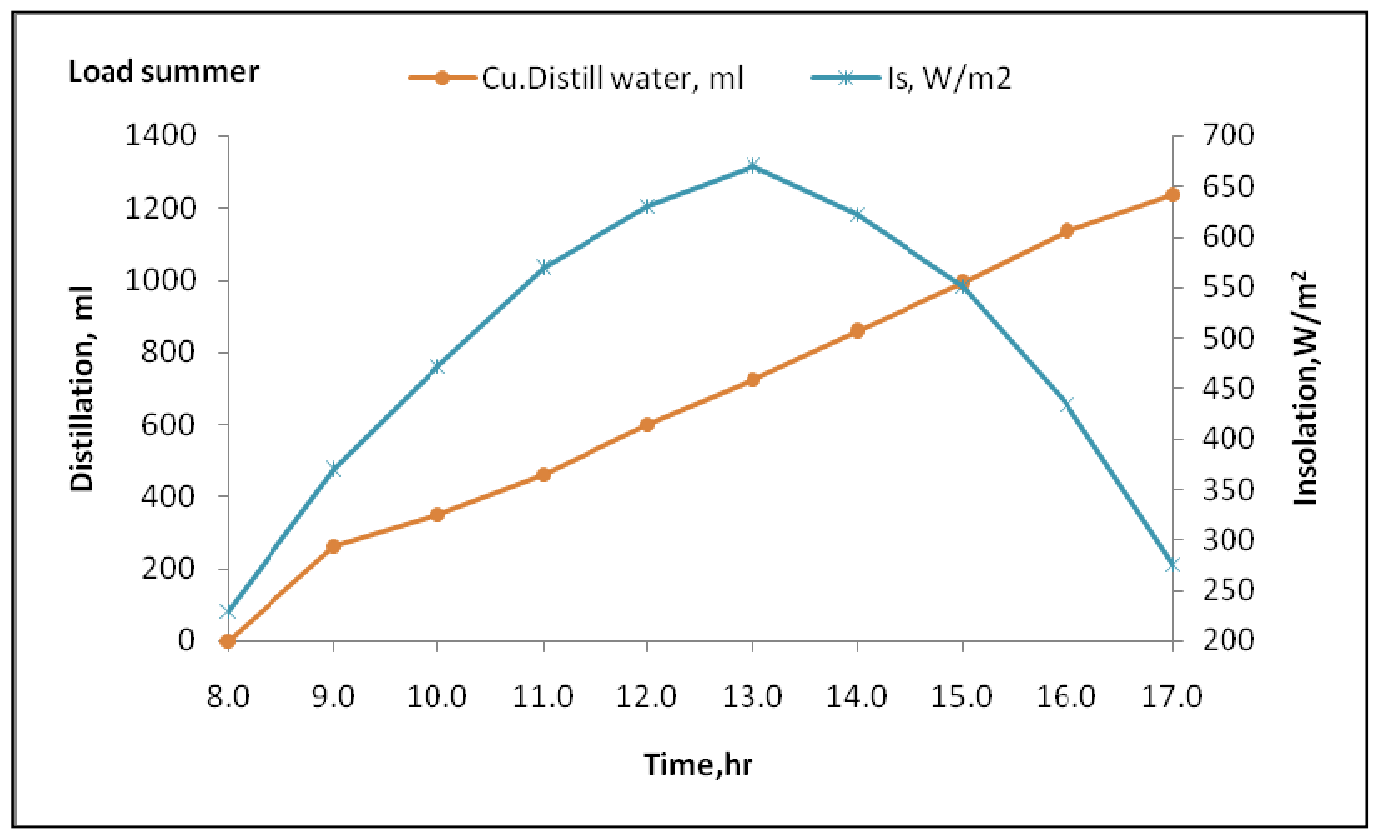

Fig. 5. W-shape solar still during load test in summer.

Table 5. Details about cost analysis of solar still.

\begin{tabular}{|c|c|c|c|}
\hline $\begin{array}{l}\text { Sr. } \\
\text { No. }\end{array}$ & Particulars & & Amount ('.) \\
\hline 1 & Total Revenue & & 3900 \\
\hline 2 & Cost of Device & & 1640 \\
\hline 3 & Cost of Energy & & Nil \\
\hline 4 & Cost of Polythene & & 210 \\
\hline \multirow[t]{2}{*}{5} & \multirow{2}{*}{$\begin{array}{l}\text { Cost of Labor, Operation and Maintenance } \\
\text { for trouble free operation of unit }\end{array}$} & Per year & 100 \\
\hline & & After every 5 year & 310 \\
\hline
\end{tabular}

accordingly evaporation was observed more after noon hours and then rate of condensation was increased than noon time as solar intensity decreased. Cumulative distilled water obtained from solar still in summer month was $1498 \mathrm{ml}$ including day and night condensation. It was observed from Fig. 5 that maximum distillation rate obtained in morning and evening hours. Highest distillation rate was observed as $262 \mathrm{ml}$ at 9 am and between $3 \mathrm{pm}$ to $4 \mathrm{pm}$ which was highest as 134 and $143 \mathrm{ml}$. Average overnight distillation observed in solar still unit was $261 \mathrm{ml}$ which was due to humidity available inside the still in night time.

Comparison of developed solar distillation units with available solar still: After evaluating the developed solar stills with available still, their results of cumulative distillation are compared and depicted in Table 4. Comparatively more distilled water was obtained from the solar still having an area of $1 \mathrm{~m}^{2}$ fabricated in fibbers with glass glazing. Average maximum temperature and humidity were more available in solar still and hence the average quantity of distilled water obtained varied from 925-2425 $\mathrm{ml} / \mathrm{m}^{2}$-day. Reason behind the maximum output from single slope solar still was proper insulation and glass glazing where as developed solar stills made with plastic wrapping over the frame which itself acted as body of solar still and glazing for maximum energy collection.

This plastic made up of $W$-shape solar still produce average distilled water as $1276 \mathrm{ml} / \mathrm{m}^{2}$-day. Comparatively lower distillation was observed in $W$-shape polythene based solar still and it might be due to the use of polythene as a glazing area and more heat loss through the unit. Comparative cost of compact nature of solar stills like single slope solar still was more than Rs.8000/- which is four times more than newly developed $W$-shape solar still. Comparative output from newly developed solar still was low but it has several advantages as it is cheapest, cost efficient and easy to clean. Its production cost was less than $0.50 /-$ and hence this unit is superior to other available unit.

Efficiency of solar still: Efficiency of solar still was calculated with following equation (Ali et.al, 2012). 
Table 6. Payback Period Analysis of distillation unit.

\begin{tabular}{llcccc}
\hline Year & Cash outflow & $\begin{array}{c}\text { PW of Cash } \\
\text { outflow }\end{array}$ & Cash inflow & $\begin{array}{c}\text { PW of Cash } \\
\text { inflow }\end{array}$ & NPW \\
\hline 1.0 & 2.0 & 3.0 & 4.0 & 5.0 & $(5)-(3)$ \\
0.0 & 1640.0 & 1640.0 & 0.0 & & -1640.0 \\
$\mathbf{1 . 0}$ & 100.0 & 90.1 & 3900.0 & 3513.5 & 3423.4 \\
2.0 & 310.0 & 100.0 & 3900.0 & 3165.3 & 3065.3 \\
3.0 & 100.0 & 73.1 & 3900.0 & 2851.6 & 2778.5 \\
4.0 & 310.0 & 204.2 & 3900.0 & 2569.1 & 2364.8 \\
5.0 & 100.0 & 59.3 & 3900.0 & 2314.5 & 2255.1 \\
6.0 & 310.0 & 165.7 & 3900.0 & 2085.1 & 1919.4 \\
7.0 & 100.0 & 48.2 & 3900.0 & 1878.5 & 1830.3 \\
8.0 & 310.0 & 134.5 & 3900.0 & 1692.3 & 1557.8 \\
9.0 & 100.0 & 39.1 & 3900.0 & 1524.6 & 1485.5 \\
10.0 & 0.0 & 0.0 & 3900.0 & 1373.5 & 1373.5 \\
\hline Total & & $\mathbf{9 1 4 . 3}$ & & $\mathbf{2 2 9 6 8 . 0}$ & $\mathbf{2 2 0 5 3 . 7}$ \\
\hline
\end{tabular}

$$
\begin{gathered}
=\frac{\text { mewd } \times \lambda / A_{b} \times(I)_{t} \times 3600}{\text { Where, }} \\
\text { Mewd- daily output, } \mathrm{kg} / \mathrm{m}^{2} \text { day } \\
\lambda \text { - latentent heat water, } \mathrm{kj} / \mathrm{kg} \\
\text { Ab- basin area } \\
\text { I-Solar insolation. } \mathrm{W} / \mathrm{m}^{2}
\end{gathered}
$$

Efficiency of developed solar still was found as $20 \%$

Total dissolved solid and $\mathbf{p H}$ : The $\mathrm{pH}$ and total dissolved solid was observed in distilled water was 7.0 and 0 ppm where in normal water, was 7.8 and 350 ppm respectively. These observed $\mathrm{pH}$ and total dissolve solid were similar with earlier researcheres (Dara, 1999, Kothari and Sengar, 2007). The data obtained pre and post distillation was well agreed with the WHO and BIS1991 standards as under permissible limit (Ashish et. al, 2014). Thus the passive still can be adopted as a green alternative to purify water in remote areas where supply of electricity is not continuous (). With concerning to above researchers distilled water could be best option for conversion into potable water with addition of minerals.

Cost economics: During the performance evaluation of solar distillation unit, different direct benefits were derived. These benefits were indicators of technical feasibility of plant. Subsequently the economics of the plant was evaluated in terms of cost per liter of distilled water through electrical backup in distillation unit (Sengar et.al.2011). The total cost that of the investment spread over the entire useful life of the plant, including initial cost, operation cost, maintenance and interest are taken in consideration for calculation of payback period.

Considering the average distilled water obtained from $W$ - shape solar still as 1.3 liter for 250 days a year. It produced 325 liters of distilled water yearly. By con- sidering the wholesale market value of distilled water ( $.12 /$ lit) and total income generated while producing 325 liters of distilled water is tabulated in Table 5.

It was observed that the cost of unit is recovered within 5 months 22 days only, i.e. the payback period of the unit was only 6 months and after that period the unit will produce net profit. Output of newly developed solar still is less compare to available distiller but payback period is minimum. It may be due to the lower cost of the unit. Benefit Cost Ratio (BCR) and Net Present Worth were observed as 2 and `.22053/- respectively (Table 6).

\section{Conclusion}

Average distilled water obtained was $1276 \mathrm{ml} / \mathrm{m}^{2}$-day from newly developed $W$-shape solar still erected on top of house. Concentration of $\mathrm{pH}$ and TDS in solar distilled water was found to be 7.0 and 0 respectively. Thermal efficiency of developed solar still was found as 20 per cent. Its production cost was less than ₹ 0.50 / - and hence this unit is superior to other available unit as its novelty.

\section{ACKNOWLEDGMENTS}

Authors are highly thankful to College of Agricultural Engineering and Technology, NAU, Dediapada for their financial support and facility.

\section{REFERENCES}

Ali, A. F. Al-Hamadani, Shukla S. K. and Dwivedi A. (2012).Experimental Performance Analysis of a Solar Distillation System with PCM Storage, International Journal of Research in Engineering and Technology (IJRET) Vol. 1, No. 6, 43-78.

Anna, M.,and Rangarajan S.(1980). Solar Radiation over India, Allied Publisher Privet Ltd., New Delhi : 404.

Arunkumar, T. Vinothkumar K. , Ahsan A, Jayaprakash R. 
and Sanjay K. (2012) Experimental Study on Various Solar Still Designs,2012, International Scholarly Research Network, ISRN Renewable Energy, , Article ID 569381,10

Ashish, K. Prashant, A. and Mohd. A. Z. (2014). Distillate water quality analysis and economics study of a passive solar still. Recent Research in Science and Technology, 6(1): $128-130$

Bouchekima, B. (2003) A small solar desalination plant for the production of drinkable water in remote arid areas of southern Algeria. Desalination, Vol. 159 , 197-204.

Brenidorfer, B. Kennedy and L. Bateman, C. O. (1995) "Solar dryer; their role in post harvest processing, Commonwealth Secretariat Marlborough house", London, Swly 5hx. 1995.

Dara, S.S.(1999). A text book on experimental and calculation in engineering chemistry, S. Chand publication, New Delhi,pp-5-13.

Joseph, J. Saravanan, R. Renganarayanan, S.(2005). Studies on a single-stage solar desalination system for domestic applications. Desalination, Vol.173, 77-82.
Kothari, S. and Sengar, S.H. (2007). Performance evaluation of solar stills. Bioved,18(1,2): 35-37, 2007.

Lashkaripour, G.R.and Zivadar, M.(2005). Desalination of brackish water in Zahedan city in Iran. Desalination Vol., 177.,1-5.

Pandey, A. K., Dinesh K, Sharma, R. Sharma U. Vijh, R. K. and Ahlawat S. P. S.(2005). Population Structure and Genetic Bottleneck Analysis of Ankleshwar Poultry Breed by Microsatellite Markers. Genetic analysis of ankleshwar poultry, 19.

Sengar, S.H, Mohod, A.G. Khandetod, Y.P. Modak, S.P. and Gupta, D.K.(2011). Design and Development of wick type solar distillation system, Journal of Soil science and Environmental Management, Vol 2(7),pp125-133.

Tarawneh, K.(2007). Effect of Water Depth on the Performance Evaluation of Solar Still, Jordan Journal of Mechanical and Industrial Engineering, Volume 1, Number 1, Sep.,23-29.

Velmurugan, V. and Srithar, K.(2011). Performance analysis of solar still based on various factor affecting the productivity-A review. Renewable and sustainable energy review 15:1294130 